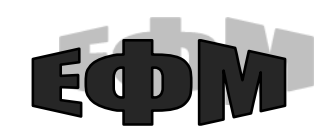

http://efm.vsau.org/

УАК 338.432:33.012.42/43:338.24

\author{
НАПРЯМИ РЕАЛІЗАЦІї \\ АЕРЖАВНОї ПІДТРИМКИ \\ АГРАРНОГО СЕКТОРУ \\ ЕКОНОМІКИ В РИНКОВИХ \\ УМОВАХ ГОСПОААРЮВАННЯ ${ }^{\odot}$
}

Л.М. ПРОНБКО,
кандидат економічних наук, доцент
кафедри адміністративного
менеджсменту

та альтернативних джерел енергії,

Н.М. КУЛИК,

викладач Верхівського

сільськогосподарського коледжсу

Вінницького національного аграрного університету

(м. Вінниця)

У статті розглядаються актуальні питання щуодо напрямів реалізації державної підтримки аграрного сектору економіки в ринкових умовах господарювання. Досліджено, щзо система державної підтримки та регулювання сільського господарства в Украӥні деформована $і$ відстає від циивілізаційного розвитку й від європейських стандартів. Автор акиентує увагу на тому, щуо негативними наслідками здійснюваної політики державного управління та регулювання в Украӥні є: порушення цінової еквівалентності і паритетних відносин між аграрним сектором та іншими сферами економіки, відсутність изілеспрямованих, науково-обтрунтованих програм розвитку аграрного сектору та розвитку села.

Обтрунтовано, що недостатньо ефективно реалізується державна підтримка у вигляді надання субсидій, дотацій і субвенщій. Причиною є недостатнє фінансування розроблених та впроваджених програм бюджетної підтримки та правил розподілу бюджетних коштів за відповідними програмними. Авторами доведено, щуо держава повинна сприяти зниженню процентних ставок на кредити, забезпечувати рівні умови діяльності в усіх регіонах України шляхом більш ефективної податкової політики, переглянути транспортні тарифи для сільськогосподарських товаровиробників $i$ стимулювати їх до розвитку власної збутової інфраструктури, щцо допоможе позбутися посередників у сільському господарстві та наблизитися до світових моделей розвитку агропромислового комплексу.

Ключові слова: державне регулювання, державна підтримка, інструменти, бюджетні кошти, програми розвитку, фінансування, пільгові кредити, фінансова підтримка.

Рис.: 2. Літ.: 15.

\title{
DIRECTIONS OF THE STATE SUPPORT REALIZATION FOR AGRARIAN SECTOR OF ECONOMY IN MARKET CONDITIONS MANAGEMENT
}

PRONKO Liudmyla, Candidate of Economic Sciences, Associate Professor of the Department of Administrative Management and Alternative Energy Sources,

고. Л. ПРОНЬКО, Н.М. КУЛИК, 2019 


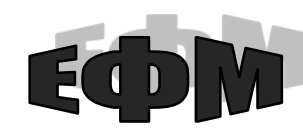

http://efm.vsau.org/

\title{
KULYK Natalia, Lecturer of Verkhivka Agrarian College of Vinnytsia National Agrarian University
}

(Vinnytsia)

The article deals with topical issues concerning the directions of the state support for the agrarian sector of economy in market conditions management. It was investigated that the system of state support and regulation of agriculture in Ukraine is deformed and lags behind civilization development and European standards. The author emphasizes that the negative consequences of the implemented policy of public administration and regulation in Ukraine are: violation of price equivalence and parity between the agrarian sector and other spheres of the economy and the lack of targeted, scientifically grounded agrarian sector development programs and rural development.

It is substantiated that state support in the form of subsidies, dotation and subventions is not being effectively implemented. The reason is lack of funding for developed and implemented budget support programs and rules for allocating budget funds, according to the relevant provision. The authors have proved that the state should help to reduce interest rates on loans, ensure equal conditions of activity in all regions of Ukraine, through a more efficient tax policy, review the transport tariffs for agricultural producers and encourage the latter to develop their own sales infrastructure. It will help to get rid of intermediaries in agriculture and to approach the world models of development of the agroindustrial complex.

Key words: state regulation, state support, tools, budget funds, development programs, financing, preferential loans, financial support.

Fig.: 2. Ref.: 15.

\section{АННОТАЦИЯ \\ НАПРАВЛЕНИЯ РЕАЛИЗАЦИИ ГОСУДАРСТВЕННОЙ ПОДДЕРЖКИ АГРАРНОГО СЕКТОРА В РЫНОЧНЫХ УСЛОВИЯХ ХОЗЯЙСТВОВАНИЯ}

\author{
ПРОНЬКО Людмила Николаевна, \\ кандидат экономических наук, доцент кафедры административного \\ менеджсмента и альтернативных источников энергии,
}

КУЛИК Наталя Николаевна, преподаватель Верховского сельскохозяйстенного коледжса Винницкого национального аграрного университета (2. Винница)

В статье рассматриваются актуальные вопросы реализации государственной поддержки аграрного сектора в рыночных условиях хозяйствования. Доказано, что система государственной поддержки и регулирования сельского хозяйства в Украине деформирована и отстает от ичивилизационного развития и от европейских стандартов. Авторы акцентируют внимание на том, что негативными последствиями проводимой политики государственного управления и регулирования в Украине являются: нарушение ценовой эквивалентности и паритетных отношений между аграрным сектором и другими сферами экономики и отсутствие целенаправленных, научно обоснованных программ развития аграрного сектора и развития села. 
Обосновано, что недостаточно эффективно реализуется государственная поддержка в виде предоставления субсидий, дотаџий и субвенщий. Причиной является недостаточное финансирование разработанных и внедренных программ бюджетной поддержки и правил распределения бюджетных средств согласно соответствующим программам.

Автором доказано, что государство должно способствовать снижению прочентных ставок по кредитам, обеспечивать равные условия деятельности во всех регионах Украины путём более эффрективной налоговой политики, пересмотреть транспортные тарифы для сельскохозяйственных товаропроизводителей и стимулировать их к развитию собственной сбытовой инфраструктуры, что поможет избавиться от посредников в сельском хозяйстве и приблизиться к мировым моделям развития агропромышленного комплекса.

Ключевые слова: государственное регулирование, государственная поддержка, инструменты, бюджетные средства, программы, финансирование, льготные кредиты, финансовая поддержка.

\section{Рис.: 2. Лит.: 15.}

Постановка проблеми. Аграрний сектор є специфічною галуззю економіки України. За часткою орних земель - 56 \% всієї території країни - Україна займає третє місце у світі (тобто тут ми, практично, є світовими лідерами). Щодо кількості працівників, зайнятих у сільському господарстві (майже 15\% станом на 2017 р.), то за цим показником Україна близька до Колумбії i Тунісу. Частка сільськогосподарського виробництва становить майже 20\% ВВП України.

Останніми роками спостерігається тенденція до зростання цього показника. При цьому в СС частка сільськогосподарського виробництва становить 1,64\% ВВП, хоча $\mathrm{CC}$ входить до світових лідерів з експорту сільськогосподарської продукції, як і США, де частка сільгоспвиробництва складає всього 1,44\% ВВП.

Подолання наслідків соціально-економічної кризи у 2010 році, яка охопила усі країни світу та ускладнила умови функціонування аграрного сектору економіки, об’єктивно потребує ефективного механізму державного регулювання.

Адаптація вітчизняного аграрного сектора до сучасних орієнтирів глобальної економіки передбачає активізацію усієї сукупності факторів, спрямованих на ефективну підтримку галузі, внесення істотних змін у політику захисту вітчизняних товаровиробників, адекватну вимогам СОТ та спрямовану на розкриття багатофункціональної ролі сільського господарства. В контексті ринкових перетворень, пов'язаних 3 напрямами реалізації державної підтримки аграрного сектору економіки набувають особливої актуальності.

Аналіз останніх досліджень і публікацій. На думку багатьох вітчизняних учених, серед яких О.М. Бородіна [2;3], П.І. Гайдуцький [4], С.В. Майстро [5], А.Г. Мазур [15], І.Й. Малий [9], П.Т. Саблук [4], та ін., застосовані інструменти державного регулювання і підтримки аграрного сектору виявилися неефективними, причому, як внутрішні, у вигляді різноманітних способів державної підтримки, так і зовнішні, які використовувалися в межах торговельно-економічних відносин 3 зарубіжними країнами.

Формулювання цілей статті. Метою дослідження є обгрунтування напрямів реалізації державної підтримки аграрного сектора в ринкових умовах господарювання. 
Виклад основного матеріалу дослідження. Будь-які трансформаційні зміни залежать від держави, а саме: від заходів, які мають враховувати сучасні напрями розвитку вітчизняного ринку, співпраці з зарубіжними виробниками, які розглядають Україну як потенційного постачальника сільськогосподарської продукції.

Розв'язання цих проблем сприятиме побудові й ефективному функціонуванню державного управління на різних напрямах формування та реалізації соціальноекономічної політики [1]. Для розвитку аграрної економіки державна підтримка має буди збалансованою і враховувати проблеми соціально-економічного розвитку держави шляхом удосконалення системи державного управління та прийняття відповідних законодавчих актів.

Основними інструментами державної підтримки виступають безвідсоткові бюджетні кредити аграрним виробникам, звільнення від оподаткування, списання i реструктуризація боргів, часткова компенсація витрат на придбання сільськогосподарської техніки і обладнання.

Однак система державної підтримки та регулювання сільського господарства в Україні деформована і відстає від цивілізаційного розвитку й від європейських стандартів.

3 переходом до ринкових відносин відбулося значне скорочення державної підтримки сільськогосподарських товаровиробників, яка у 1986-1988 роках становила 78\% валового доходу галузі й була вдвічі вищою, ніж у країнах Свропи (37 \%). У 2004-2014 роках державна підтримка галузі скоротилася до нуля, а в країнах Свропи збереглася на рівні 32\%.

Сьогодні витрати Державного бюджету України на підтримку аграрного сектора становлять 5-6\% бюджетних видатків. Разом з тим, бюджетна підтримка практично повністю нівелюється існуючим диспаритетом цін. На 100 грн бюджетних виплат припадає 100 грн цінових витрат, тоді як в ЄС, навпаки, на 100 євро бюджетних виплат фермерам припадає 130 євро цінової підтримки [2].

Крім того, державна підтримка цін i виробництва надається сільськогосподарським підприємствам, в яких виробляють лише 40,7\% валової продукції галузі і зайнято менше третини працездатних сільських жителів [3]. Селянські та переважна більшість фермерських господарств такої підтримки практично не одержують.

Таким чином, можна стверджувати, що на даний час негативними наслідками здійснюваної політики державного управління та регулювання в Україні є:

- порушення цінової еквівалентності і паритетних відносин між аграрним сектором та іншими сферами економіки;

- відсутність цілеспрямованих, науково обгрунтованих програм розвитку аграрного сектору та розвитку села.

Тому постають питання щодо вдосконалення цінової політики, яка б відновила паритетність і забезпечила позитивну цінову підтримку сільськогосподарських виробників, сприяла вибору інструментів підтримки та реалізації шляхів виходу аграрної галузі із затяжної кризи через застосування заходів державного протекціонізму. Такий підхід сприятиме зниженню рівня нееквівалентності в товарообміні аграрного сектору 3 іншими галузями економіки та забезпечить ефективне функціонування сільськогосподарського виробництва [4, с.126-128]. 
Державна підтримка сільського господарства в Україні охоплює бюджетне фінансування програм і заходів, які спрямовуються на розвиток галузі, пільговий режим оподаткування, часткову компенсацію процентних ставок за користування кредитами комерційних банків, списання безнадійної заборгованості перед бюджетом, підтримку розширеного відтворення в сільському господарстві і захисту інтересів споживачів сільськогосподарської продукції [5].

Основні засади бюджетного фінансування сільського господарства визначені в Законах України «Про державну підтримку сільського господарства України» [6], «Про основні засади державної аграрної політики на період до 2018 року» [7], а також у «Державній цільовій програмі розвитку українського села на період до 2018 року» та ін.

У країнах ЄС державну підтримку сільського господарства здійснюють шляхом надання аграріям дешевих кредитів, підтримання твердих цін, виконання безпосередніх виплат тощо. У Європі під державне регулювання підпадає $90 \%$ цін на сільськогосподарську продукцію у вигляді субсидій для підтримки аграріїв через високі ціни на засоби виробництва [9].

В Україні обсяг державної підтримки сільськогосподарського виробництва постійно зменшується. Так за період 2008-2017 років номінальний показник державного фінансування агропромислової галузі скоротився на 43,3\%, а вартість валової продукції у порівняльних цінах 2012 року зросла на 30\%. Питома вага фінансування залишається мізерною - у середньому 15,8\%.

Класифікація механізму державної підтримки зображена на рис. 1.

Для порівняння, у США рівень державної підтримки сільського господарства становить $40 \%$ від вартості виробленої сільськогосподарської продукції, у країнах ЄС - 35\%, в Японії та Франції - $60 \%$.

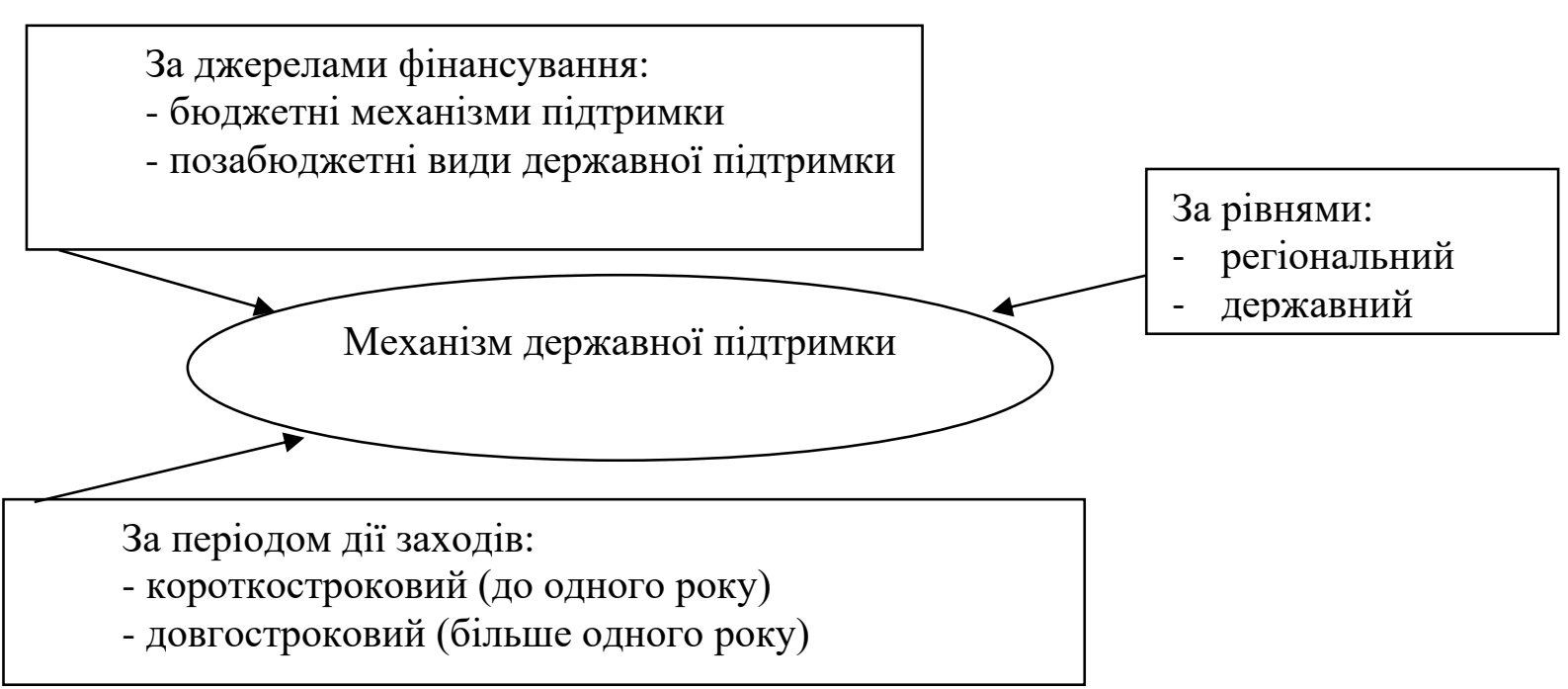

\section{Рuc. 1. Механізм державної підтримки аграрного сектору економіки України Джерело: сформоване автором на основі [5]}

Нині у сфері державної підтримки агропромислового комплексу визначають такі основні напрями [10]:

- розробка та реалізація різних програм розвитку сільського господарства;

- підтримка сільськогосподарських товаровиробників за рахунок дотацій, субсидій і субвенцій; 
- надання виробникам кредитів і позик на пільгових умовах;

- страхування аграрної галузі;

- розвиток зернового потенціалу.

Зрозуміло, що важливе значення мають не лише обсяги державної підтримки, а й механізми їі надання.

У сфері аграрної політики для досягнення поставленої мети держава використовує різноманітні інструменти, зокрема фінансову підтримку сільськогосподарських товаровиробників.

Головними інструментами державної підтримки сільськогосподарських підприємств є дотації, субсидії, субвенції. Основні види держаної підтримки наведено на рис. 2.

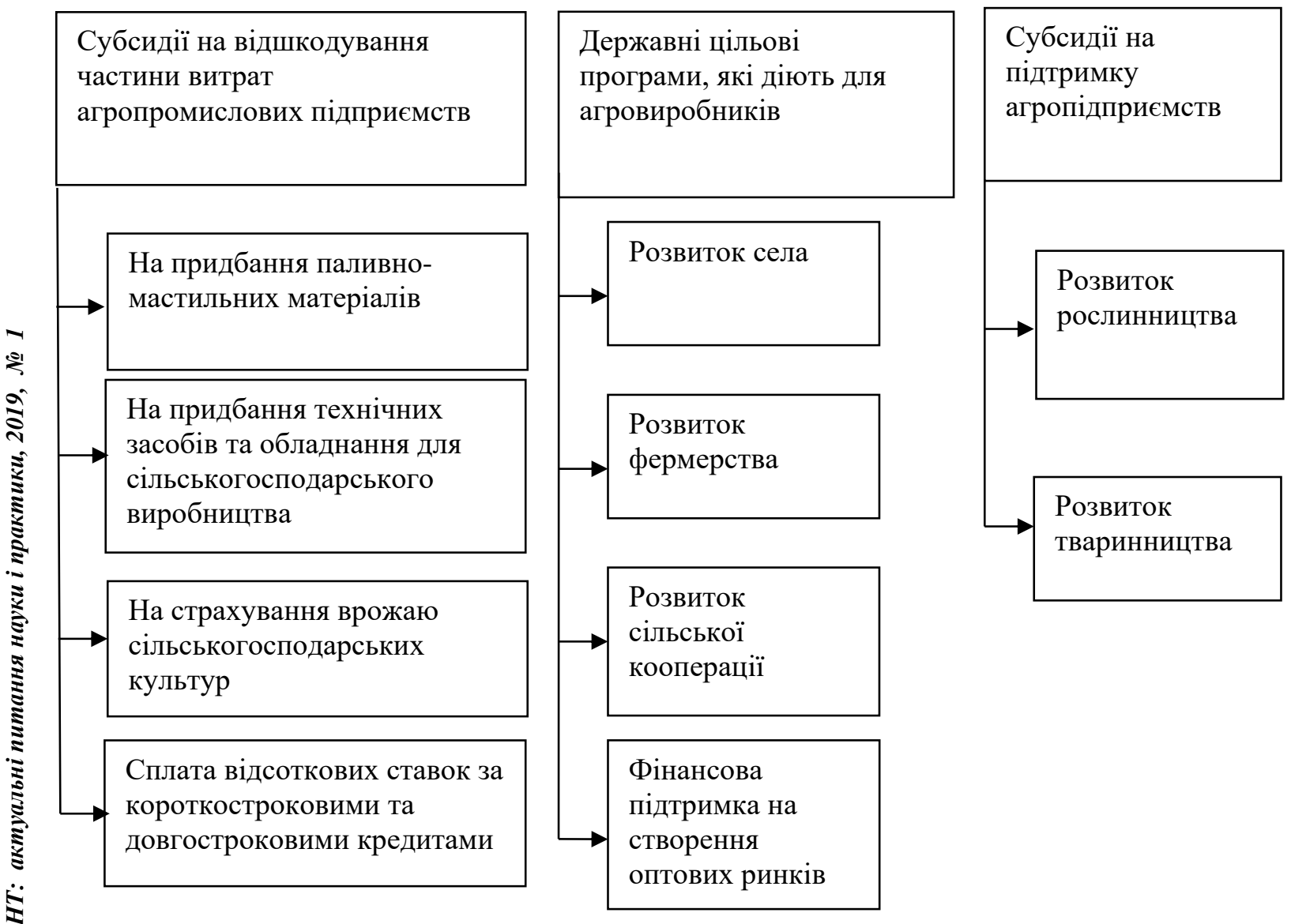

\section{Рис. 2. Види державної підтримки аграрних підприсмств}

Джерело: сформоване автором на основі [10]

На жаль, на сьогодні недостатньо ефективно реалізується державна підтримка у вигляді надання субсидій, дотацій i субвенцій, оскільки виробники сільськогосподарської продукції або не отримують фінансових ресурсів унаслідок браку коштів, або отримують їх зі значним запізненням у часі [11]. Це зумовлено тим, що розроблені та впроваджені програми бюджетної підтримки часто недофінансовуються, а правила розподілу бюджетних коштів за відповідними 
програмами схвалюються на щорічній основі, а отже, змінюються з року в рік (тобто виробники сільськогосподарської продукції часто не отримують підтримки, коли вона їм терміново потрібна).

Крім того, потрібно врахувати корупційні прояви, наявність обмежень та ускладнень при доступі до програм бюджетної підтримки для сільгоспвиробників.

Складною та незрозумілою є і процедура отримання державної підтримки, порядок надання документів для отримання субсидій, що також породжує недовіру до держави з боку сільгоспвиробників.

Отже, на нашу думку, державна підтримка має бути переорієнтована 3 сільськогосподарського виробництва на підтримку індивідуальних проектів, що визначаються заздалегідь відомими категоріями, які забезпечують їх високу ефективність.

Держава повинна сприяти зниженню процентних ставок на кредити, забезпечувати рівні умови діяльності в усіх регіонах України шляхом більш ефективної податкової політики, переглянути транспортні тарифи для сільськогосподарських товаровиробників і стимулювати їх розвивати власну збутову інфраструктуру, що допоможе позбутися посередників у сільському господарстві та наблизитися до світових моделей розвитку агропромислового комплексу [12, с. 212-215].

Отже, державна підтримка $є$ сукупністю різних важелів i інструментів пільгового фінансування найбільш вразливих підприємств і галузей АПК.

Тому сільськогосподарським товаровиробникам доцільно зосередитися на:

- підвищенні рівня виробництва сільськогосподарської продукції, що сприятиме нарощенню кормової бази тваринництва та збільшить експортний потенціал країни;

- збільшенні обсягів виробництва молока та м'яса;

- зниженні рівня залежності від імпорту продукції сільського господарства.

Розв'язання таких проблем можливе лише за належного державного регулювання та підтримки галузей АПК.

Отже, на нашу думку, напрями державної підтримки виробників сільськогосподарської продукції мають враховувати [13]:

- міжнародну ефективність виробництва, що визначатиметься показниками конкурентоспроможності сільськогосподарської продукції, якості та рівнем захисту вітчизняних товаровиробників на агропродовольчому ринку;

- регіональну ефективність - зміцнення i використання регіональних конкурентних переваг, підвищення інвестиційної привабливості регіонального АПК;

- національну ефективність - рівень держаної підтримки доходів виробників сільськогосподарської продукції та стимулювання їхньої інноваційної діяльності.

Ще одним важливим напрямом удосконалення економічного механізму державної підтримки є підвищення доступності кредитів і позик, метою якого $є$ зростання фінансової стійкості галузі. Аграрії повинні створювати необхідні умови для розширеного відтворення за допомогою кредитних ресурсів. Одночасно має бути модифікована схема видачі пільгових кредитів.

Адже як переконує світовий досвід - основою створення раціонального та стійкого економічно збалансованого сільськогосподарського виробництва $\epsilon$ цілеспрямована державна підтримка. 


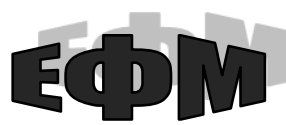

http://efm.vsau.org/

Висновки. Отже, для того, щоб сільськогосподарське виробництво розвивалося більш ефективно та підвищувався рівень його конкурентоспроможності, потрібно відрегулювати процес надання державної фінансової підтримки сільськогосподарським виробникам, забезпечити його збільшення та ефективне використання відповідно до принципів ринкової економіки та підходів до державного заохочення виробництва сільськогосподарської продукції в інших державах.

Врегулювання вимагає також i система прямого державного сприяння аграрному сектору. Дотації та відшкодування 3 державного бюджету варто сплачувати, передусім, виробникам сільськогосподарської продукції, а головну частину коштів варто спрямовувати на фінансову підтримку програм, які спроможні забезпечувати стабільний розвиток аграрного сектору.

\section{Список використаних джерел}

1. Гадзало Я.М., Лузан Ю.Я. Сучасні виклики модернізації аграрної політик України. Вісник аграрної науки. 2017. С. 9-22.

2. Бородіна О.М.,Киризюк С.В. Інституційні засади змін державної підтримки аграрного сектора України відповідно до вимог СОТ. Економіка і прогнозування. 2017, № 8. C. 87-105.

3. Бородіна О.М. Могильний О.М. Коригування політики державної підтримки сільського господарства України. Економіка АПК. 2017, № 6. С. 55-61.

4. Аграрна реформа в Україні / П.І. Гайдуцький та ін.; за ред. П.І. Гайдуцького. Київ, 2016. 424 с.

5. Майстро С.В. Напрями державної підтримки аграрного сектора та її вплив на конкурентоспроможність продукції на світовому ринку Сталий розвиток економіки. URL: http://www.academy.gov.ua/ej/ej2/txts/galuz/05msvpsr. pdf.

6. Про державну підтримку сільського господарства: України Закон України від 24 червня 2004 р.№ 1447. URL: http://zakon.rada.gov.ua.

7. Про основні засади державної аграрної політики на період до 2018 року: Закон України від 18.10.2005 p. № 2982. URL: http://zakon.rada.gov.ua.

8. Про державний бюджет України на 2017 рік: Закон України від 21 грудня 2016 p. № 1801. URL: http://zakon.rada.gov.ua.

9. Малий І. Й. Про романтизацію приватної власності на землю і кризу аграрного сектора. Економічна теорія. 2008, № 3. С. 11-20.

10. Пуцентейло П. Напрями удосконалення державної підтримки сільського господарства України. Торгівля і ринок України: темат. зб. наук. праџь. 2013, вип. 36. C. $256-264$.

11. Чернієнко О.О. Сучасні проблеми державного регулювання ринку цукру. Економіка АПК. 2012, № 2. С. 61-65.

12. Бетлій М. Аграрний сектор України на шляху до євро інтеграції: монографія. Ужгород: IBA, 2016, 496 с.

13. Булат М.А. Напрями державної бюджетної підтримки сільського господарства. Економіка АПК, 2010, № 3. С. 46-50.

14. УКАБ: підтримка сільського господарства досягла рекордно низького рівня: URL: http://www.unian.ua/news/476952-ukab-pidtrimka-silskogo-gospodarstvadosyagla-rekordno-nizkogo-rivnya.html.

15. Mazur A., Kubai O. Spatial organization of regional economic development. ЕКОНОМІКА. ФІНАНСИ. МЕНЕДЖМЕНТ: актуальні питання науки і практики. 2018, № 3. C.7-17. 


\section{References}

1. Gadzalo Y.M., Luzan Yu.Ya. (2017). Suchasni vyklyky modernizatsiyi ahrarnoyi polityky Ukrayiny [Modern Challenges of Modernizing the Agrarian Policy of Ukraine ]. Visnyk ahrarnoyi nauky - Bulletin of Agrarian Science, November, 9-22 [in Ukrainian].

2. Borodina O.M. (2017). Instytutsiyni zasady zmin derzhavnoyi pidtrymky ahrarnoho sektora Ukrayiny vidpovidno do vymoh SOT [Institutional Principles of Changing State Support to the Agrarian Sector of Ukraine in accordance with WTO]. Ekonomika i prohnozuvannya - Economy and Forecasting, 8, 87-105 [in Ukrainian].

3. Borodina O.M. (2016). Koryhuvannya polityky derzhavnoyi pidtrymky silskoho hospodarstva Ukrayiny [Adjustment of the policy of state support of agriculture of Ukraine ]. Ekonomika APK - Economy of AIC, 6,55-61 [in Ukrainian].

4. Ahrarna reforma v Ukrayini [Agrarian reform in Ukraine] P.I. Gaiduckiy, P.T. Sabluk, Yu.O. Lupenkoet.al. (2016). Kiev: Tekst [in Ukrainian].

5. Master S.V. Napryamy derzhavnoyi pidtrymky ahrarnoho sektora ta yiyi vplyv na konkurentospromozhnist produktsiyi na svitovomu rynku [The directions of state support to the agrarian sector and its impact on the competitiveness of products in the world market].Retrieved from: http://www.academy.gov.ua [in Ukrainian].

6. Pro derzhavnu pidtrymku silskoho hospodarstva [On State Support to Agriculture]. Law of Ukraine. Retrieved from: http://zakon2.rada.gov.ua. [in Ukrainian].

7. Pro osnovni zasady derzhavnoyi ahrarnoyi polityky na period do 2018 roku [On the Basic Principles of the State Agrarian Policy for the Period until 2018]. The Law of Ukraine.Retrieved from: http://zakon2.rada.gov.ua [in Ukrainian].

8. Pro derzhavnyy byudzhet Ukrayiny na 2017 rik [About the state budget of Ukraine for 2017]. Law of Ukraine Retrieved from: http://zakon2.rada.gov.ua [in Ukrainian].

9. Malyi I.Y. (2008). Pro romantyzatsiyu pryvatnoyi vlasnosti na zemlyu i kryzu ahrarnoho sektora. [About Romanticization of Private Ownership on Land and the Crisis of the Agrarian Sector]. Economic Theory, 3, 11-20 [in Ukrainian].

10. Putsteniylo P. (2013). Napryamy udoskonalennya derzhavnoyi pidtrymky silskoho hospodarstva Ukrayiny [The Directions of Improvement of State Support to Agriculture in Ukraine]. Torhivlya i rynok Ukrayin: temat. zb. nauk. prats - Trade and Market of Ukraine: topic collection of scientific papers. Donetsk: DonNUET, 36, 256-264 [in Ukrainian].

11. Chernenko O.O. (2012). Suchasni problemy derzhavnoho rehulyuvannya rynku tsukru [Modern problems of state regulation of sugar market]. Ekonomika APK - Economy of AIC, 2, 61-65 [in Ukrainian].

12. Ahrarnyy sektor Ukrayiny na shlyakhu do yevrointehratsiyi [Agrarian Sector of Ukraine on the Way to Euro Integration]. Monograph (2016). Betliy M. et.al, Uzhgorod: IVA [in Ukrainian].

13. Bulat M.A. (2010). Napryamy derzhavnoyi byudzhetnoyi pidtrymky silskoho hospodarstva [Directions of state budget support of agriculture]. Ekonomika APK Economy of AIC, 3, 46-50 [in Ukrainian].

14. UKAB: pidtrymka silskoho hospodarstva dosyahla rekordno nyzkoho rivnya [UCAB: agricultural support has reached a record low level]. Retrieved from: http://www.unian.ua [in Ukrainian]. 
15. Mazur A., Kubai O. (2018). Spatial organization of regional economic development [Spatial organization of regional economic development]. EKONOMIKA. FINANSY. MENEDZHMENT: aktualni pytannya nauky i praktyky - ECONOMICS. FINANCES. MANAGEMENT: topical issues of science and practice, 3, 7-17 [in Ukrainian].

\section{Відомості про авторів}

ПРОНЬКО Людмила Миколаївна - кандидат економічних наук, доцент кафедри адміністративного менеджменту та альтернативних джерел енергії, Вінницький національний аграрний університет (21008, м. Вінниця, вул. Сонячна, 3, e-mail: pronkoL@ukr.net).

КУЛИк Наталя Миколаївна - викладач Верхівського сільськогосподарського коледжу Вінницького національного аграрного університету (21008, м. Вінниця, вул. Сонячна, 3, e-mail: pronkoL@ukr.net).

PRONKO Liudmyla - Candidate of Economic Sciences, Associate Professor of the Department of Administrative Management and Alternative Energy Sources, Vinnytsia National Agrarian University (21008, Vinnytsia, 3 Soniachna Str., e-mail: pronkoL@ukr.net).

KULYK Natalya - Lecturer of Verkhivka Agrarian College of Vinnytsia National Agrarian University (21008, Vinnytsia, 3 Soniachna Str., e-mail: pronkoL@ukr.net).

ПРОНЬКО Людмила Николаевна - кандидат экономических наук, доцент кафедры административного менеджмента и альтернативных источников энергии, Винницкий национальный аграрный университет (21008, г. Винница, ул. Солнечная, 3, e-mail: pronkoL@ukr.net).

КУЛИК Наталия Николаевна - преподаватель Верховского сельскохозяйстенного коледжа Винницкого национального аграрного университета (21008, г. Винница, ул. Солнечная, 3, e-mail: pronkoL@ukr.net). 